\title{
SOSIALISASI DAN PENDAMPINGAN PENCEGAHAN KERUSAKAN LINGKUNGAN DI KECAMATAN SUNGAI PINANG, SAMARINDA
}

\author{
Vita Pramaningsih"1), Rosana2), Yudi Sulistiyanto²), Ratna Yuliawati"1) \\ ${ }^{1) K e s e h a t a n ~ L i n g k u n g a n, ~ F a k u l t a s ~ K e s e h a t a n ~ M a s y a r a k a t, ~ U n i v e r s i t a s ~ M u h a m m a d i y a h ~ K a l i m a n t a n ~ T i m u r, ~ S a m a r i n d a, ~}$ \\ Kalimantan Timur, Indonesia \\ ${ }^{2)}$ Bidang Pengendalian Pencemaran dan Kerusakan Lingkungan, Dinas Lingkungan Hidup Kota Samarinda, Kalimantan \\ Timur, Indonesia \\ Corresponding author : Vita Pramaningsih \\ E-mail : vp799@umkt.ac.id
}

Diterima 16 November 2021, 29 November 2021, Disetujui 29 November 2021

\begin{abstract}
ABSTRAK
Kerusakan lingkungan hidup Kota Samarinda menjadi perhatian khusus bagi pemerintah dan dinas terkait, terutama Dinas Lingkungan Hidup (DLH) Kota Samarinda. Permasalahan yang sering terjadi pada musim hujan adalah banjir dan tanah longsor. Masyarakat kurang informasi tentang penyebab, upaya pencegahan dan perlindungan diri dari bencana. Tujuan kegiatan pengabdian masyarakat ini adalah melakukan sosialisasi dan pendampingan pencegahan kerusakan lingkungan di Kecamatan Sungai Pinang, Samarinda. Metode yang digunakan adalah pengarahan untuk memberi informasi daerah Kecamatan Sungai Pinang yang rawan bencana longsor dan banjir. Pelaksanaan diskusi dengan memaparkan laporan per kelurahan di Kecamatan Sungai Pinang. Permasalahan yang disampaikan setiap kelurahan menjadi bahan pertimbangan pihak DLH Kota Samarinda bersama pihak terkait untuk mengatasinya. Kegiatan ini bermitra dengan Dosen Prodi D3 Kesehatan Lingkungan, Universitas Muhammadiyah Kalimantan Timur. Hasil kegiatan yaitu Kelurahan Mugirejo rawan longsor karena daerah bertebing, padat pemukiman rumah dan banjir saat musim hujan, masyarakat belum memahami kondisi lahan yang cocok untuk membangun rumah. Kelurahan Sungai Pinang Dalam, masyarakat maupun pengusaha melakukan pembangunan kurang memperhatikan kondisi lahan. Kelurahan Bandara rawan banjir saat musim hujan karena gorong-gorong buntu penuh sampah, sedimen dan tertutup, begitu juga dengan Kelurahan Bandara dan Gunung lingai. Perlu adanya koordinasi di tingkat RT, Kelurahan, Kecamatan sampai ke Dinas terkait untuk mensosialisasikan lahan kritis, rawan longsor, pengelolaan sampah dan drainase bersih.
\end{abstract}

Kata kunci: kerusakan lingkungan; longsor; banjir; pengelolaan sampah.

\begin{abstract}
Environmental degradation in Samarinda is a special concern for the government and related agencies, especially Department of Environment Samarinda City. Problems that often occur in the rainy season are floods and landslides. The community lacks information of causes and prevention and self protection efforts from disasters. The purpose of this community service activity is to carry out socialization and assistance to prevent environmental degradation in Sungai Pinang District, Samarinda. Methode used is directives to provide information on areas of Sungai Pinang District which are prone to landslides and floods. Implementation of the discussion by presenting reports per Village in Sungai Pinang District. The problems presented by each Village are considered by Department of Environment Samarinda City together with related parties to solved the problems. This activity is partnership with a lecturer in Diploma Environmental Health, Universitas Muhammadiyah Kalimantan Timur. Result of the activity are Mugirejo Village is prone to landslides because the are is rocky, densely populated with houses and floods during the rainy season, people do not understand the conditions of land suitable for building houses. Sungai Pinang Dalam Village, the community and businessman ignore land condition. Bandara Village is prone flooding during the rainy season because the culverts are clogged with garbage, sediment and clogged, as same as with Bandara and Gunung lingai. There needs coordination between official in district, subdistrict and Government to socialize critical land, prone landslides, waste management and clean drainage.
\end{abstract}

Keywords: environmental degradation; landslide; flood; waste management. 


\section{PENDAHULUAN}

Lingkungan Hidup adalah kesatuan ruang dengan semua benda, daya, keadaan, dan makhluk hidup, termasuk manusia dan perilakunya, yang mempengaruhi alam itu sendiri, kelangsungan perikehidupan, dan kesejahteraan manusia serta makhluk hidup lain (UU RI No. 32, 2009). Permasalahan lingkungan hidup sangat beragam mulai dari pencemaran maupun kerusakan lahan yang berdampak terhadap kerusakan lingkungan. Kota Samarinda memiliki permasalahan yang krusial yaitu pencemaran air, permasalahan sampah, banjir dan tanah longsor. Sosialisasi dan pendampingan terhadap masyarakat perlu dilakukan untuk memberikan informasi dan edukasi dalam upaya pencegahan pencemaran dan kerusakan lingkungan. Hal ini dilakukan mulai dari tingkat kecamatan yang dihadiri oleh perwakilan kelurahan, sehingga seluruh lapisan masyarakat dapat terjangkau.

Perkembangan Kota Samarinda sangat pesat, mulai dari banyaknya pengembang perumahan baru dan pusat perbelanjaan. Hal ini mendukung kebutuhan masyarakat dan menyerap tenaga kerja. Tetapi disisi lain menimbulkan beberapa permasalahan lingkungan. Salah satunya perubahan penggunaan lahan yang berdampak pada berkurangnya area resapan air. Hal ini berdampak pada bencana banjir yang semakin mengancam kota Samarinda. Samarinda merupakan daerah dengan kontur yang rendah. Limpasan air permukaan (runoff) saat hujan akan bermuara ke Sungai Mahakam yang dipengaruhi oleh pasang surut air laut (Sulaiman et al., 2020). Hal ini menambah permasalahan disaat terjadi banjir sehingga air tidak dapat langsung melimpas ke muara jika sedang pasang. Pembangunan di Kota Samarinda mengurangi area resapan air, system drainase dan folder tidak memadai yang menjadi salah satu penyebab tingginya genangan air di Samarinda (Warsilan, 2019).

Kota Samarinda merupakan daerah hilir sehingga menerima limpasan dari daerah hulu. Pengelolaan lahan di daerah hulu sangat berpengaruh dalam upaya pengelolaan daerah resapan air dan pengendalian banjir. Genangan atau banjir di Kota Samarinda bersumber dari banjir kiriman dari daerah hulu, banjir lokal dan banjir akibat pasang Sungai Mahakam (Sulaiman et al., 2020). Beberapa faktor alam penyebab banjir di Kota Samarinda antara lain tingginya curah hujan, topografi wilayah dan pasang surut Sungai Mahakam. Faktor manusia antara lain pertumbuhan penduduk yang menuntut peningkatan infrastruktur, pemukiman, sarana air bersih, Pendidikan serta fasilitas masyarakat.
Pengelolaan lingkungan hidup perlu dilakukan di semua kalangan baik masyarakat, pelaku usaha, industri, civitas akademik maupun pemerintah melalui dinas terkait. Perusahaan memiliki program Corporate Social Responsibility (CSR) untuk pengelolaan lingkungan dan pemberdayaan masyarakat (Mulyani et al., 2019). Pengelolaan lingkungan dapat dilakukan bersama-sama dengan mitra sehingga dapat memberikan sumbangsih untuk keberhasilan program. Semakin banyak pihak yang terlibat dalam pengelolaan lingkungan maka diharapkan kerusakan lingkungan dapat dikendalikan.

Berdasarkan latar belakang tersebut, maka Dinas Lingkungan Hidup Kota Samarinda melakukan sosialisasi pencegahan kerusakan lingkungan di beberapa kecamatan di Kota Samarinda. Salah satu kegiatan dilaksanakan bersama dengan Dosen D3 Kesehatan Lingkungan, Universitas Muhammadiyah Kalimantan Timur sebagai mitra melakukan Sosialisasi dan Pendampingan Pencegahan Kerusakan Lingkungan di Kecamatan Sungai Pinang, Samarinda.

Kecamatan Sungai Pinang terdiri dari 5 Kelurahan, yaitu Kelurahan Bandara, Kelurahan Gunung Lingai, Kelurahan Mugirejo, Kelurahan Sungai Pinang Dalam dan Kelurahan Temindung Permai. Berdasarkan luasa wilayah, Kelurahan terluas di Kecamatan Sungai Pinang adalah Kelurahan Mugirejo. Sebaran luasan wilayah kelurahan disajikan pada Tabel 1 (Badan Pusat Statistik, 2021)

Tabel 1. Luas Wilayah Kelurahan di Kecamatan Sungai Pinang

\begin{tabular}{lcc}
\hline Desa/Kelurahan & $\begin{array}{c}\text { Luas Wilayah } \\
\left(\mathbf{K m}^{2}\right)\end{array}$ & Persentase \\
\hline $\begin{array}{l}\text { Temindung } \\
\text { Permai }\end{array}$ & 1,30 & 3,81 \\
\hline Bandara & 8,59 & 25,15 \\
\hline $\begin{array}{l}\text { Sungai Pinang } \\
\text { Dalam }\end{array}$ & 8,97 & 26,26 \\
\hline Mugirejo & 10,94 & 32,02 \\
\hline Gunung Lingai & 4,36 & 12,76 \\
\hline Jumlah & $\mathbf{3 4 , 1 6}$ & $\mathbf{1 0 0 , 0 0}$ \\
\hline
\end{tabular}

(Sumber: BPS Kota Samarinda, 2021)

\section{METODE}

Metode yang digunakan dalam kegiatan Pengabdian Masyarakat ini adalah dengan ceramah memeberikan sosialisasi, pengarahan dan edukasi untuk memberi informasi daerah Kecamatan Sungai Pinang yang rawan bencana longsor dan banjir. Kemudian dilanjutkan diskusi dengan memaparkan laporan per Kelurahan di Kecamatan Sungai Pinang. Kegiatan ini mengundang seluruh pihak Kelurahan dan RT untuk hadir dalam kegiatan ini. Terakhir 
evaluasi dengan memaparkan proses pengaduan di Dinas Lingkungan Hidup jika terjadi permasalahan yang dapat merusak lingkungan.

\section{HASIL DAN PEMBAHASAN Pemaparan Materi}

Pelaksanaan Sosialisasi dan

Pendampingan mengenai Pencegahan Kerusakan Lingkungan dilaksanakan di aula Kecamatan Sungai Pinang. Kegiatan dilaksanakan pada hari Kamis, 30 September 2021. Materi yang disampaikan antara lain tentang perubahan bentang alam, alih fungsi lahan, Geo hazard, pencemaran air, udara dan tanah. Kerusakan lingkungan terjadi karena terjadinya pencemaran dan kerusakan lahan. Pemberian materi didepan para undangan yaitu seluruh RT dan pihak kelurahan di wilayah Kecamatan Sungai Pinang, Gambar 1.

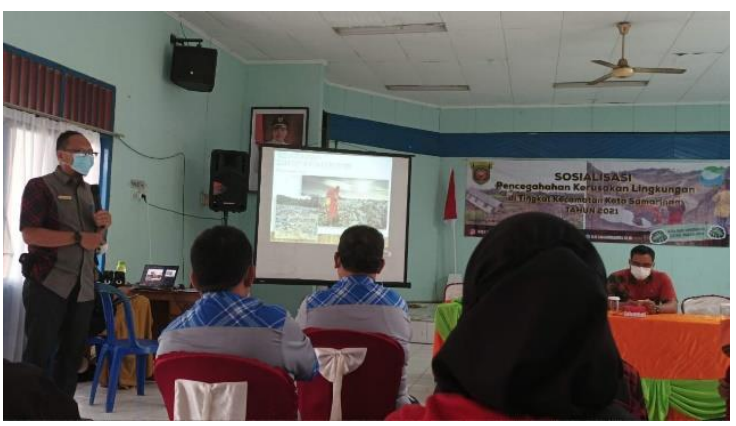

Gambar 1. Pemaparan Materi (Sumber: Penulis, 2021)

Permasalahan lingkungan di Kecamatan Sungai Pinang adalah banjir, longsor dan pencemaran udara dan air akibat aktivitas rumah potong ayam. Bentang alam Kecamatan Sungai Pinang Sebagian berupa perbukitan. Perubahan bentang alam seperti memotong perbukitan untuk dibuat Kawasan pemukiman. Hal ini perlu diperhatikan bentuk bentang alamnya untuk menghindari terjadinya longsor. Selain itu juga perlu diperhatikan kontrusi bangunan yang cocok dengan kondisi tersebut serta tingkat keamanannya. Jika memang tidak memungkinkan untuk pemukiman atau pembangunan maka haris disesuaikan peruntukannya. Hal ini biasanya sudah tertuang dalam peta Rencana tata Ruang Kota (RT/RW).

Alih fungsi lahan, misal membuka hutan untuk dimanfaatkan menjadi pertanian /perkebunan atau bahkan perumahan dan pertambangan. Beberapa permasalahan lahan di Kota Samarinda yang di pinggiran kota banyak dibuka dan dikaplingkan. Hal ini tidak diimbangi dengan ketersediaan Ruang Terbuka Hijau (RTH). TRH berfungsi sebagai daerah resapan air sehingga meminimalisir jumlah limpasan air (runoff) di saat terjadi hujan (Warsilan, 2019). Pembangun Kota Samarinda hendaklah bijaksana harus diimbangi dengan pengelolaan lingkungan yang baik sehingga pembangunan kota terwujud, daya dukung lingkungan lingkungan tidak terlampaui dan kesejateraan masyarakat tercapai.

Permasalahan banjir di Samarinda yang Sebagian besar melanda Kecamatan Sungai Pinang, perlu kerjasama dari berbagai pihak untuk menanggulanginya. Pemerintah memiliki peranan besar melalui pimpinan daerah dan jajarannya. Program pemerintah untuk memajukan Kota Samarinda maju dan sejahtera hendaklah selalu menyelipkan upaya perlindungan lingkungan di setiap programnya (Alwafi Ridho Subarkah, 2018). Pemerintah Kota Samarinda selalu berupaya melakukan perbaikan di sektor penanggulangan bencana dan pengendalian kerusakan lingkungan. Pemerinta berperan aktif dalam upaya menanggulangi banjir di Kota Samarinda Bersama dengan masyarakat (Suryadi, 2020). Harapannya hal ini perlu ditingkatkan dalam mewujudkan Kota Samarinda yang bersih, nyaman dan sejahtera.

\section{Diskusi}

Pemaparan materi telah selesai dilaksanakan, kemudian dilanjutkan diskusi dengan peserta dari RT dan kelurahan di wilayah Kecamatan Sungai Pinang seperti pada Gambar 2. Setiap Kelurahan memaparkan permasalahan lingkungan baik pencemaran maupun kerusakan lingkungan berupa tanah longsor yang terjadi di wilayahnya. Segala uneg-uneg, permasalahan dan kendala yang dihadapi di lapangan dicurahkan dalam diskusi ini. Pihak Dinas Lingkungan hidup menanggapi dan memberikan masukan sesuai dengan ranahnya.

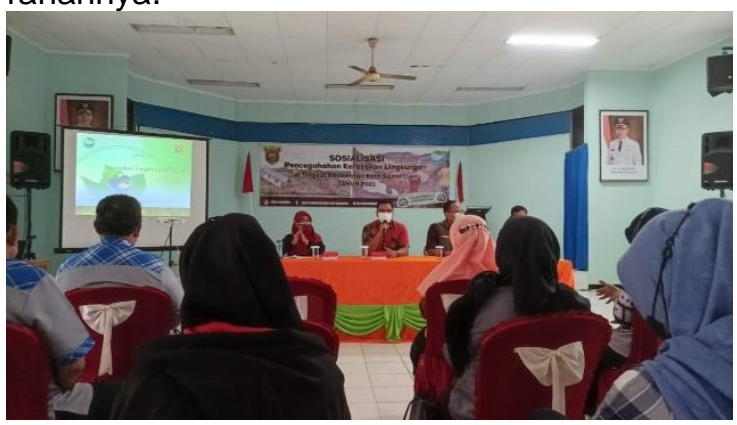

Gambar 2. Pelaksanaan Diskusi

Permasalahan yang berhubungan dengan pencegahan pencemaran dan kerusakan lingkungan adalah ranah Dinas Lingkungan Hidup. Sedangkan Penanganan Bencana yang terjadi adalah ranah Badan Penanggulangan Bencana Daerah (BPBD). Tabel 2 merupahan hasil diskusi dalam 
kegiatan pengabdian masyarakat berupa sosialisasi dan pendampingan pencegahan kerusakan lingkungan di Kecamatan Sungai Pinang, Samarinda.

Bencana tanah longsor dan banjir terjadi di Kelurahan Mugirejo, di daerah lereng dan pemukiman. Pihak kelurahan sudah melaporkan kejadian tersebut ke BPBD. Bencana longsor juga terjadi di Kelurahan Sungai Pinang Dalam, di pemukiman sampai ke daerah makam. Hal ini juga sudah lapor ke BPBD. Solusi sementara adalah membuat informasi untuk masyarakat mengenai pengendalian permasalahan lingkungan, dengan dibuat spanduk yang bertuliskan "Rawan longsor" sehingga masyarakat mengetahui kondisi di daerah tersebut.

Tabel 2. Hasil Diskusi Sosialisasi dan

Pendampingan Pencegahan Kerusakan

Lingkungan di Kecamatan Sungai Pinang

\begin{tabular}{lll}
\hline Kelurahan & $\begin{array}{c}\text { Permasalahan } \\
\text { Lingkungan }\end{array}$ & \multicolumn{1}{c}{ Solusi } \\
\hline $\begin{array}{l}\text { Temindung } \\
\text { Permai }\end{array}$ & - banjir & $\begin{array}{c}\text { - Pengendalian } \\
\text { lapor DLH } \\
\text { untuk }\end{array}$ \\
& & pendampingan \\
\hline Bandara & - banjir & - Pengendalian \\
& & lapor DLH \\
& & untuk \\
& pendampingan \\
\hline Sungai & - Longsor & - Lapor BPBD \\
Pinang & & karena \\
Dalam & & bencana \\
& & longsor \\
\hline Mugirejo & - longsor & - Lapor BPBD \\
& - banjir & karena \\
& & bencana \\
& & longsor dan \\
& & banjir \\
\hline Gunung & - banjir & Pengendalian \\
Lingai & & lapor DLH \\
& & untuk \\
& & pendampingan \\
\hline Sumber: &
\end{tabular}

Sumber: Penulis, 2021

Prioritas penanganan pemukiman tangguh bencana longsor adalah berdasar dari segi arsitektur: pondasi bangunan, lokasidan struktur bangunan. Sedangkan dari segi network: drainase lingkungan, jalan dan air bersih (Utami et al., 2021). Kondisi lahan dan sekitarnya harus menjadi perhatian utama sebelum memilih lokasi tersebut untuk membangun suatu bangunan. Hal ini berpengaruh terhadap pembiayaan, maintenance dan keselamatan. Beberapa daerah yang rawan lonsor dan bencana lain, sudah dipetakan di RT/RW. Hal ini sebagai informasi ke masyarakat saat akan mengurus ljin Mendirikan Bangunan (IMB).
Permasalahannya adalah masyarakat kebanyakan tidak mengurus IMB sebelum membangun suatu bangunan.

$$
\text { Kelurahan Temindung Permai, }
$$

Bandara dan Gunung Lingai memiliki permasalahan banjir sehingga diperlukan pengajuan atau pelaporan ke Dinas Lingkungan Hidup untuk dilakukan pendampingan dan sosialisasi mengenai upaya-upaya pencegahan dan pengendalian banjir. Selain itu pengaduan juga dapat dilakukan jika di daerahnya terdapat permasalhan pencemaran lingkungan dari sumber tertentu yang perlu dilakukan pengendalian. Pengendalian banjir dapat diupayakan melalui pemberdayaan masyarakat dengan mengedukasi masyarakat, mengoptimalkan peran komunitas, melalui kebijakan dan secara teknis melalui pembuatan sumur resapan dan biopori jika memungkinkan (Sartika, 2019). Hal ini perlu diperhatikan kondisi wilayah, topografi, intensitas curah hujan. Jika sumur resapan dan biopori diperkirakan tidak mampu menampung air limpasan dan tidak memungkin ataupun kurang optimal dapat dilakukan alternatif lain. Salah satunya adalah dengan pemompaan jika memang genangan / banjir cukup tinggi. Salah satu penyebab banjir adalah tumpukan sampah di gorong-gorong / drainase yang tertutup sehingga sudah untuk proses pembersihannya.

\section{Prosedur Pengaduan}

Prosedur pengaduan ke Dinas Lingkungan Hidup Kota Samarinda untuk permasalahan lingkungan dengan konteks sebagai upaya pencegahan pencemaran dan kerusakan lingkungan. Upaya pencegahan merupakan upaya preventif sebelum terjadi bencana alam di lingkungan. Prosedur / mekanisme penyelesaian pengaduan dan perusakan lingkungan di wilayah Kota Samarinda sesuai dengan Keputusan Walikota Samarinda No. 660/210/HK-KS/III/2013 tentang Pembentukan Pos Pengaduan Lingkungan Hidup Kota Samarinda. Pengaduan juga dapat melalui online ke website www.lapor.go.id, atau Instagram @dlh.samarinda. Pengaduan dengan mengisis form seperti pada Gambar 3. 


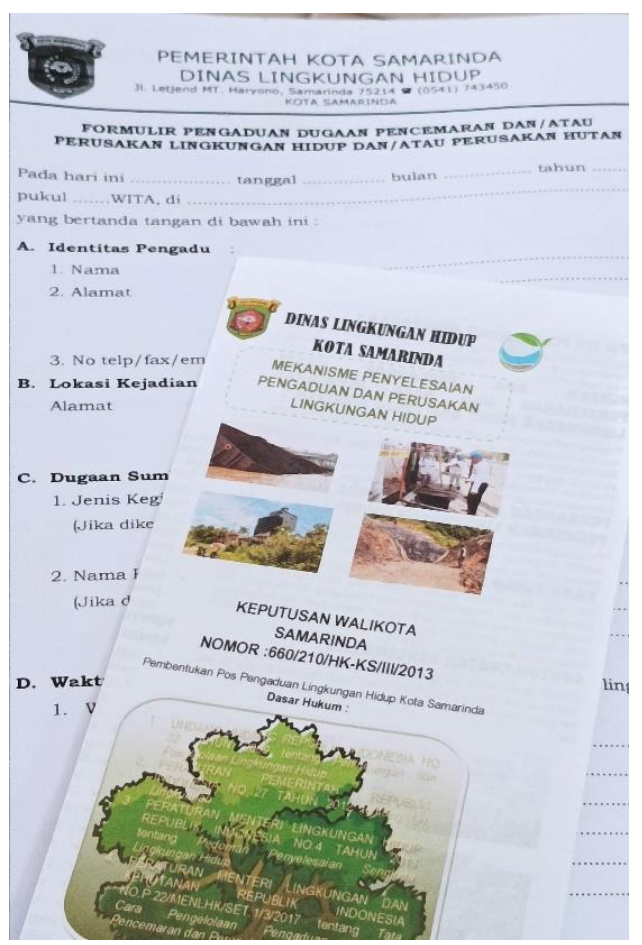

Gambar 3. Form Pengaduan Sumber: Penulis, 2021

\section{SIMPULAN DAN SARAN}

Kesimpulan dari kegiatan pengabdian masyarakat ini adalah masyarakat memperoleh edukasi dan wawasan baik secara teori maupun kondisi lapangan tentang pencegahan kerusakan lingkungan sehingga masyarakat lebih memahami kondisi lingkungan di sekitar tempat tinggalnya. Saran dari kegiatan ini adalah perlu adanya kerjasama dari berbagai pihak terkait dalam mewujudkan keberhasilan melakukan pencegahan banjir dan tanah longsor di Samarinda.

\section{UCAPAN TERIMAKASIH}

Kami ucapkan terima kasih kepada pihak tim Dinas Lingkungan Hidup Kota Samarinda, Bidang Pengendalian Pencemaran dan Kerusakan Lingkungan yang telah menjadikan kami Dosen D3 Kesehatan Lingkungan Universitas Muhammadiyah Kalimantan Timur sebagai mitra dalam pelaksanaan pengabdian masyarakat ini.

\section{DAFTAR RUJUKAN}

Alwafi Ridho Subarkah. (2018). Analisis Wacana Lingkungan dalam Debat Politik Kandidat Pilgub Kalimantan Timur Tahun 2018. Community, 4(2), 140-154.

Badan Pusat Statistik, K. S. (2021). Kecamatan Sungai Pinang dalam Angka. Badan Pusat Statistik Kota Samarinda.

Keputusan Walikota Samarinda No. 660/210/HK-KS/III/2013 tentang Pembentukan Pos Pengaduan
Lingkungan Hidup Kota Samarinda.

Mulyani, D. D. W. I., Ekonomi, F., \& Timur, J. (2019). Implementasi Program Corporate Social Responsibility ( Csr ) Dalam Pemberdayaan. EJournal Administrasi Bisnis, 7(4).

Sartika, D. (2019). Pengelolaan Banjir Di Kota Samarinda Berbasis Pemberdayaan Masyarakat Melalui Sumur Biopori. Jurnal Kebijakan Pembangunan, 14(14), 63-76.

Sulaiman, M. E., Setiawan, H., Jalil, M., Purwadi, F., S, C. A., Brata, A. W., \& Jufda, A. S. (2020). Analisis Penyebab Banjir di Kota Samarinda. Jurnal Geografi Gea, 20(1), $39-43$. https://doi.org/10.17509/gea.v20i1.22021

Suryadi, N. (2020). Peran Pemerintah Dalam Menanggulangi Banjir Di Kota Samarinda. EJournal Ilmu Pemerintahan, 2020(2), 425-436.

Utami, S., Ekasari, K., \& Saputra, R. M. (2021). Penggunaan AHP guna penentuan prioritas penanganan permukiman tangguh bencana longsor. Jurnal Pengelolaan Lingkungan Berkelanjutan (Journal of Environmental Sustainability Management), 4(2), 498-512. https://doi.org/10.36813/jplb.4.2.498-512

UU RI No. 32, U. R. (2009). Undang-Undang Republik Indonesia No. 32 Tahun 2009 tentang Perlindungan dan Pengelolaan Lingkungan Hidup. UU Republik Indonesia. https://doi.org/10.1038/132817a0

Warsilan, W. (2019). Dampak Perubahan Guna Lahan Terhadap Kemampuan Resapan Air (Kasus: Kota Samarinda). Jurnal Pembangunan Wilayah \& Kota, 15(1), 70. https://doi.org/10.14710/pwk.v15i1.20713 